\title{
Disclosure: Journal of Accounting and Finance
}

ISSN: 2797-0531 (p), 2807-7423 (e)

Website: http://journal.iaincurup.ac.id/index.php/disclosure

DOI: http://doi.org/10.29240/disclosure.v1i2.3775

Vol. 1, No. 2, 2021 | Pages: 155-172

\section{Implementasi PSAK NO. 106 Akuntansi Musyarakah Pada Produk Pembiayaan Kepemilikan Rumah}

\author{
Soleha \\ Institut Agama Islam Negeri (IAIN) Curup, Indonesia \\ soleha_mr@yahoo.com
}

\begin{abstract}
As on of the Business measuring tools, accounting is inseparable from Business Activities owing to its function to provide information about the financial condition and as a medium of accountability between parties. Therefore, accounting standards are essentially required to prevent from any kinds of abuse of Authority and Disputes. Some Research findings highlights that most of the banks have not implemented accounting standards. This Research uses qualitative normative approach by researching financing managers as the Research subjects representing the bank institution. The data Wet collected through instrument of interview and documentation. The data Wet analyzed with qualitative analysis. In practice, this bank has complied with accounting standards. Such statement of accounting standards applied to home financing Products is its conformity with statement of Financial Accounting Standards (PSAK) No. 106 on Musyarakah Accounting.
\end{abstract}

Keywords: PSAK No. 106 Musyarakah Accounting, Musyarakah Mutanaqisah, House Ownership

\begin{abstract}
Abstrak
Akuntansi merupakan sebagai salah satu alat ukur bisnis dan sesuatu yang tidak dapat dipisahkah dari kegiatan bisnis. Karena akuntansi dapat memberikan informasi tentang kondisi keuangan dan sebagai media pertanggung jawaban antar pihak. Dari itu di perlukan standar akuntansi untuk mencegah penyalahgunaan wewenang dan perselisihan. Beberapa hasil penelitian mengatakan kebanyakan dari bank tersebut belum menerapkan standar akuntansi. Selain itu fenomena yang beredar dimasyarakat masih memilih bank
\end{abstract}


Soleha | Implementasi PSAK NO. 106 Akuntansi Musyarakah Pada Produk Pembiayaan Kepemilikan Rumah

konvensional karena mereka beranggapan kedua bank tersebut sama dan tidak jauh berbeda. Padahal semua sistem dan mekanisme untuk bank syariah telah diatur dalam fatwa DSN-MUI, begitu juga dengan konsep bagi hasil. Karena itu peneliti tertarik untuk melakukan penelitian pada produk pembiayaan kepemilikan rumah. Bagaimana implementasi akad musyarakah mutanaqisah pada produk pembiayaan kepemilikan rumah, bagaimana penerapan standar akuntansi yang diterapkan pada Bank Muamalat Kantor Cabang Pembantu Curup dan kesesuaiannya dengan Pernyataan Standar Akuntansi Keuangan (PSAK) NO. 106 tentang Akuntansi Musyarakah. Penelitian ini menggunakan pendekatan normatife kualitatif. Subjek diambil dari lembaga yang akan diteliti yaitu manager pembiayaan. Teknik pengumpulan data menggunakan instrument wawancara dan dokumentasi. Teknik analisa data yaitu analisis kualitatif. Implementasi yang dilakukan oleh Bank Muamalat Kantor Cabang Pembantu Curup secara umum hampir sama dengan bank konvensional. Pada prakteknya bank ini sudah menerapkan standar akuntansi. Pernyataan standar akuntansi yang diterapkan pada produk pembiayaan kepemilikan rumah sudah sesuai dengan Pernyataan Standar Akuntansi Keuangan (PSAK) NO.106 tentang Akuntansi Musyarakah.

Keywords: PSAK No. 106 Akuntansi Musyarakah, Musyarakah Mutanaqisah, Kepemilikan Rumah

\section{Pendahuluan}

Penelitian ini dilakukan untuk mengetahui apakah Bank Muamalat Kantor Cabang Pembantu Curup sudah menerapkan Pernyataan Standar Akuntansi Keuangan pada produk kepemilikan rumah sesuai dengan akad yang mereka gunakan. Selain itu untuk mengetahui bagaimana aplikasi akad musyarakah mutanaqisah pada bank tersebut. Tujuan penelitian untuk mengetahui apakah bank tersebut sudah menerapkan PSAK pada produk kepemilikan rumah. Semoga penelitian ini dapat memberikan informasi dan memberikan kepercayaan kepada masyarakat luas bahwa kesyariahannya bukan sekedar label bahwa bank syariah sudah menerapkan sesuai dengan standar akuntansi yang ditetapkan.

Penelitian yang dilakukan oleh Putri Kamilatur Rohmi tahun 2020 yaitu Implementasi akad musyarakah mutanaqisah pada pembiayaan kepemilkan rumah di Bank Muamalat Lumajang. Dari hasil yang didapat 
bahwa akad musyarakah mutanaqisah memberikan kemudahan untuk nasabalah dalam melakukan pembiayaan KPR karena memberikan jangka waktu yang lama dan angsuran yang relative lebih murah.(Rohmi, 2020)

Penelitian yang dilakukan oleh Edwin Rahmat tahun 2019 yaitu analisa pembiayaan property menggunakan akad MMQ (Musyarakah Mutanaqisah). Dari hasil penelitian didapat banyak kelemahan pada akadmusyarakah mutanaqisah dan belum maksimal untuk peningkatan profit pada bank tersebut. (Rahmat, 2019)

Penelitian yang dilakukan oleh Muhammad Rafi Ashsiddiqqy tahun 2020 mengenai implementation of aqad musyarakah mutanaqisah (MMQ) take over financing on KPR Products in Sharia Banks. The result showed the implementation MMQ agreement, take over financing for KPR productsis in a good category, although there are several indicators in the sufficient category. (Ashsiddiqqy et al., 2020)

Penelitian yang dilakukan oleh Muhammad Anwar Zainudin 2018 mengenai Akad Musyarakah Mutanaqisah dalam sistem perbankan syariah. Dari hasil penelitian diperoleh bahwa akad musyarakah mutanaqisah (MMQ) menjadi solusi alternative untuk mengoptimalisasi potensi ekonomi masyarakat. (Zainuddin, 2018)

Penelitian yang dilakukan oleh Rinrin Warisni Pribadi tahun 2019 yaitu pemebiayaan hunian syariah kongsi akad musayarakah mutanaqisah perspektif undang-undang no. 21 tahun 2008 tentang perbankan syariah. Dari hasil penelitian didapat bahwa pembiayaan hunian syaraiah yang diterapkan telah sesuai dengan undang-undang. Memenuhi rasa keadilan antara kedua belah pihak dilihat dari pembagian imbalan ketika asset diijarahkan sudah memenuhi ketentuan dalam artian memenuhi rasa keadilan dari kedua belah pihak begitujuga dengan pembebanan seluruh biaya yang timbul diperbolehkan dibebankan kepada pihak nasabah asalkan disepakati oleh kedua belah pihak pada saat akad berlangsung. (Pribadi, 2019)

\section{Metode penelitian}

Penelitian merupakan kegiatan ilmiah yang dilakukan untuk mengembangkan serta memperkaya ilmu pengetahuan. Pada penelitian ini dilakukan menggunakan pendekatan normative kualitatif mengenai 
Penerapan PSAK No. 106 sebagai alat ukurnya. Penelitian yang dilakukan menggunakan instrument wawancara. Subjek informan pada penelitian ini diambil dari pihak internak dari lembaga tersebut yaitu dengan para pihak yang terkait mengelola pembiayaan kepemilikan rumah.

\section{Hasil penelitian dan pembahasan}

Bank Muamalat merupakan bank syariah pertama yang membuka kantor layanan di Kota Curup. Ada banyak sekali produk dari bank tersebut mulai dari penghimpunan dana, pembiayaan, produk jasa dan jasa layanan. Salah satu pembiayaan yang diberikan Bank Muamalat ialah Pembiayaan Hunian Syariah. Pembiayaan ini membantu para nasabah yang ingin memiliki rumah baru maupun bekas, apartemen, ruko, kios maupun pengalihan take-over dari bank lain.

Pembiayaan hunian syariah ini memiliki dua akad yaitu akad musyarakah mutanaqisah dan akad murabahah. Pada bank muamalat pembiayaan ini dikenal dengan sebutan KPR IB. KPR IB Pembelian menggunakan akad murabahah dan KPR IB Kongsi menggunakan akad Musyarakah mutanaqisah. KPR IB Kongsi merupakan salah satu jenis pembiayaan kepemilikan rumah dengan menggunakan akadmusyarakah mutanaqisah. Akad musyarakah mutanaqisah merupakan akad kerjasama dimana nantinya kepemilikan asetnya berkurang dari salah satu pihak disebabkan pembelian secara bertahap oleh pihak lain. Akad yang digunakan dari pembiayaan tersebut tentu saja memiliki kegunaan dan fungsi yang berbeda.

Beberapa persyaratan yang diberlakukan oleh Bank Muamalat untuk pembiayaan kepemilikan rumah secara individu, yaitu:

1. Mengisi formulir permohonan pembiayaan

2. Identitas pribadi:

a. Fotocopy KTP Suami/Istri

b. Fotoco[y Kartu Keluarga

c. Surat Persetujuan Suami/Istri

d. Fotocopy Surat Nikah/ Cerai

e. NPWP Pribadi

3. Data penghasilan

a. Karyawan 
1) Surat keterangan bekerja dari kantor/Surat referensi

2) Data penghasilan tambahan

3) Slip gaji asli (3bulan terakhir)

4) Cash ratio pendapatan dengan angsuran maksimal 35\%

b. Wiraswasta

1) Akte pendirian

2) SIUP, NPWP, TDK, SK Domisili dan usaha berdiri minimal 2tahun

3) Neraca dan laporan laba rugi (2 tahun terakhir)

4) Fotocopy buku rekening koran (1tahun terakhir)

c. Data jaminan

1) Tanah dan bangunan (asli diserahkan sebelum pengikatan)

2) Mobil

a) Surat penawaran dasar/ surat pesanan kendaraan (difa mobil baru)

b) BPKB Mobil/ Surat persyaratan dasior

c) Fotocopy STNK

d) Umur mobil atau kendaraan tidak lebih dari 5tahun

d. Biaya-biaya

1) Administrasi bank $1.5 \%$

2) Biaya notaris

3) Premi asuransi

Beberapa persyaratan yang diberlakukan oleh Bank Muamalat untuk pembiayaan kepemilikan rumah secara koperasi, yaitu:

1. Surat permohonan pembiayaan

2. Legalitas koperasi

a. Fotocopy akte pendirian

1) Fotocopy akte perubahanan (jika ada)

2) Fotocopy AD/ART

3) Fotocopy surat keterangan domisili (SKD) dari kelurahan setempat

4) Fotocopy pengesahan dari Departemen Koperasi

5) Fotocopy NPWP, TDP, SIUP

6) Fotocopy susunan pengurus yang disahkan oleh Departemen Koperasi 
Soleha | Implementasi PSAK NO. 106 Akuntansi Musyarakah Pada Produk Pembiayaan Kepemilikan Rumah

b. Fotocopy laporan keuangan minimal 2tahun terakhir

3. Fotocopy KTP Pengurus Koperasi

4. Fotocopy mutasi rekening Koran/ tabungan 3 bulan terakhir

5. Surat pernyataan penanggung yang ditandatangani oleh pengurus koperasi + stempel dan bendahara pemotong gaji/ personalia (perusahaan induk) + materai

6. Asli SK Pegawai negeri

7. Daftar daftar nominal anggota yang mengajukan terdiri atas nama, tanggal lahir (maksimal usia 54tahun pada akhir perjajian pembiayan), gaji. Plafon, cash ratio $23 \%$ dan kegunaan yang ditandatangani oleh pengurus koperasi stampel dan bendahara pemotong gaji/ personalia + material + stampel

8. Maksimum plafon pembiayaan sampai dengan Rp 25.000.000 jika lebih dari maksimum plafon dimintakan maka harus ada jaminan tambahan

9. Copy KTP anggota yang mengajukan surat nikah, kartu keluarga, dan asli surat pendudukan suami/ istri anggota

10. Copy SK pengangkatan bendahara pemotong gaji/ personalia

11. Copy KTP bendahara pemotong gaji/ personalia

12. Biaya-biaya
a. Biaya administrasi $1,5 \%$ perplafon
b. Biaya notaris
c. Premi asuransi

Beberapa persyaratan yang diberlakukan oleh Bank Muamalat untuk pembiayaan kepemilikan rumah secara usaha, yaitu:

1. Surat permohonan pembiayaan

2. Company profil

3. Legalitas perusahaan

a. Copy akte pendirian

b. Cop surat pengesahan departemen kehakiman

c. Copy akte perubahan (jika ada)

d. Copy surat keterangan domisili dari kelurahan setempat

e. Copy NPWP, TDP dan SIUP yang masih berlaku

f. Copy KTP komisaris dari Direksi

4. Analisa keuangan perusahaan 
a. Neraca dan laba rugi minimal dua tahun terakhir

b. Copy PO, Kontrak Kerja, Kualisasi transaksi usaha dan lain-lain

5. Copy rekening mutasi bank giro 3 bulan terakhir dan bukan rekening atas nama perorangan

6. Peruntukkan pembiayaan pembelian barang modal

a. Surat penawaran penjualan

b. Surat pernyataan penjual untuk menyerahkan faktur/ BPKB jika dijadikan sebagai jaminan

c. Copy kuitansi pembelian

d. Asli faktur/ BPKB jika dijadikan sebagai jaminan

7. Data jaminan

a. Copy SHM/ SHGB

b. Copy PBB dua tahun terakhir

c. Copy IMB/ surat keteranagn kelurahan

d. Copy KTP suami/ istri, surat nikah, kartu keluarga, dan asli surat persetujuan suami/ istri untuk jaminan perorangan (asli SHM/ SHGM, IMB, dan PBB diberikan ke bank sebelum pengikatan notaries dilaksanakan).

8. Biaya- biaya

a. Biaya Appreisal dibayar dimuka jika jaminan diluar wilayah

b. Biaya administrasi $1,5 \%$ perplafon

c. Biaya notaris

d. Premi asuransi barang jaminan

Diatas beberapa persyaratan yang diberlakukan oleh Bank Muamalat untuk calon nasabah baik secara individu, koperasi dan usaha.

Selain persyaratan, ada beberapa ketentuan yang diberlakukan oleh Bank Muamalat untuk calon nasabah Pembiayaan Kepemilikan Rumah Muamalat iB, yaitu:

1. Calon nasabah usia produktif

Pastinya berwarga Negara Indonesia dan berdomisili di Indonesia. Dengan usia minimum 21 tahun dan maksimum umur 55 tahun untuk pegawai dan 60 tahun untuk wiraswasta atau profesional pada saat jatuh tempo. Khusus untuk pegawai instansi/perusahaan boleh melebihi ketentuan diatas dengan syarat menyerahkan bukti bahwa akan tetap bekerja di instansi/ perusahaan yang sama atau 
Soleha | Implementasi PSAK NO. 106 Akuntansi Musyarakah Pada Produk Pembiayaan Kepemilikan Rumah

tempat lain dan dapat diverifikasi kebenarannya dengan kewenangan pemutusan ada pada pejabat pemegang kewenangan memutus pembiayaan sesuai limit kewenangan yang dimiliki

2. Pekerjaan dengan ketentuan sebagai berikut:

a. Pegawai dengan status pegawai tetap dan kontrak.

b. Wiraswasta atau Profesional

3. Berpenghasilan

Dimana pada penghasilan ini batasan pinjaman tidak boleh melebihi 40\% dari total penghasilan. Jika sepasang suami istri sama-sama memiliki penghasilan maka dapat dilakukan penggabungan penghasilan yang dinamakan Hybread.

Contoh Perhitungan untuk pengabungan penghasilan, yaitu: Rasio gaji \% x (Penghasilan Suami + Penghasilan istri)

Contoh Kasus:

Jika Suami mempunyai penghasilan sebesar Rp 1.000.000,- /bulan dan istri mempunyai penghasilan Rp 500.000,- /bulan. Berapakah angsuran maksimal dari keduanya?

Rasio gaji \% x (Penghasilan Suami + Penghasilan istri) $40 \% \times(1.000 .000+500.000)$ $=900.000,-$

Jadi angsuran maksimum, yaitu sebesar Rp 900.000,- /bulan

Selain penghasilan, calon nasabah juga harus bersedia untuk:

a. Membuka rekening tabungan di Bank Muamalat atas nama yang bersangkutan

b. Dan memberikan dokumen standar yang dibutuhkan untuk Pembiayaan Kepemilikan Rumah Muamalat sebagai berikut:

Keterangan:

1) Bukti/ catatan transaksi bisnis hanya diminta apabila diperlukan oleh anggota komite atau financing risk officer untuk mendukung proses analis

2) SIUP tidak berlaku bagi perusahaan yang dikecualikan sesuai dengan keputusan menteri perdagangan yang berlaku

3) NPWP pribadi hanya untuk permohonan pembiayaan diatas Rp 50 juta (kecuali ditentukan lain secara tertulis oleh kantor bank Indonesia setempat) bagi calon nasabah yang tidak memiliki NPWP pribadi harus menyerahkan dokumen sebagai berikut: 
Copy NPWP Perusahaan, dan Surat pernyataan bahwa ybs bersedia menyerahkan NPWP pribadi jika suatu saat diminta oleh bank. Apabila pembiayaan diatas Rp 100 juta wajib menyerahkan NPWP, Format surat pernyataan pada lampiran.

Pernyataan Standar Akuntansi Keuangan (PSAK) NO. 106 tentang ketentuan musyarakah berisi tentang pengakuan dan pengukuran, penyajian, dan pengungkapan yang dikeluarkan oleh Ikatan Akuntansi Indonesia (IAI). Pengakuan meruapakan proses pembantukan suatu pos yang memenuhi definisi unsur serta kriteria pengakuan yang sesuai dengan standar akuntansi dalam laporan neraca dan laba rugi. Pengukuran adalah proses penetapan jumlah uang untuk mengakui dan memasukkan setiap unsure laporan keuangan dalam neraca atau laporan laba rugi. Pernyataan Standar Akuntansi Keuangan (PSAK) NO. 106 tentang ketentuan musyarakah berisi tentang pengakuan dan pengukuran, penyajian, dan pengungkapan.

Kesesuaian perlakuan akuntansi yang terjadi di Bank Muamalat Kantor Cabang Pembantu Curup terhadap PSAK No. 106, Bank Muamalat Kantor Cabang Pembantu Curup sebagai mitra pasif pada pembiayaan musyarakah.

1. Pengakuan

a. Pencatatan pada saat pembiayaan musyarakah diberikan kepada nasabah:

Investasi musyarakah yang disepakai oleh bank (M) dan nasabah (S) diakui pihak bank pada saat pembayaran kas kepada nasabah yaitu sebesar Rp 21.000.000. dengan demikian dinyatakah sesuai dengan PSAK.

b. Pencatatan atas pembebanan biaya yang dikeluarkan pada saat akad:

Dalam realisasi pembiayaan terdapat biaya-biaya yang harus dikeluarkan oleh pihak nasabah untuk menentukan kelayakan akad tersebut dan tidak dapat diakui sebagai bagian dari pembiayaan ini kecuali ada persetujuan dari seluruh mitra, sebesar Rp 7.000.000 (biaya adm dan notaris). Dengan demikian sesuai dengan PSAK. 
Soleha | Implementasi PSAK NO. 106 Akuntansi Musyarakah Pada Produk Pembiayaan Kepemilikan Rumah

c. Pencatatan atas penerimaan pendapatan bagi hasil pada 31 Juni 2000:

Laba masing-masing pihak ditentukan seuai kesepakatan bersama dari kedua belah pihak yang disetujui diawal akad. Pada bulan juni 2000 bank menerima pendapatan dari nasabah sebesar Rp 900.000 maka bank langsung melalui laba periode tersebut. Dengan demikian sesuai dengan PSAK.

d. Pencatatan atas bagian bank yang belum diterima setelah akad berakhir:

Bagian bank yang belum diterima pada akhir akad diakui sebagai piutang sebesar Rp 1.350.000. dengan demikian pihak bank sesuai dengan PSAK.

2. Pengukuran

a. Pencatatan pada saat pembiayaan musyarakah diberikan kepada nasabah:

Bank mengukur pembiayaan musyarakah dalam bentuk kas atau uang tunai dan dinilai sebesar uang yang dibayarkan kepada nasabah yaitu senilai Rp 21.000.000. dengan demikian pihak bank sesuai dengan PSAK.

b. Pencatatan atas pelunasan pembiayaan musyarakah:

Pengembalian dana bank atas investasi musyarakah pada akhir akad diukur sebesar jumlah kas atau uang tunai yang dibayarkan pada awal akad yaitu sebesar Rp 21.000.000. dengan demikian pihak bank sesuai dengan PSAK.

c. Pencatatan atas penerimaan pendapatan bagi hasil pada tanggal 31 Juni 2000 beserta modal pembiayaan musyarakah yang dikembalikan pada tahun pertama.

Pengembalian dana bank atas investasi musyarakah menurun diukur sebesar jumlah kas yang disetorkan pada awal akad dikurangi jumlah pengembalian dari mitra aktif dan kerugian sebesar Rp 21.000.000 yang dikembalikan secara bertahap selama 8tahun, dimana pertahunnya modal bank dikembalikan sebesar Rp 3.000.000 dan ditambah dengan pendapatan bagi hasil pada tahun tersebut. Dengan demikian pihak bank sesuai dnegan PSAK. 
3. Penyajian

a. Pencatatan pada saat pembiayaan musyarakah diberikan kepada nasabah:

Pada saat realisasi pembiayaan musyarakah pihak bank menyajikan pencatatan dengan mendebet pembiayaan musyarakah yang diberikan sebesar $\mathrm{Rp} 21.000 .000$ dan mengkredit kas atau rekening giro sebesar Rp 21.000.000. dengan demikian ini tidak sesuai dnegan PSAK, seharusnya pembiayaan musyarakah yang diberikan dicatat dalam jurnal sebagai investasi musyarakah.

\section{Pengungkapan}

Mitra mengungkapkan dalam hal-hal yang terkait transaksi musyarakah tetapi tidak terbatas

Wawancara dengan bapak sumardianto bahwa ia menjelaskan bank muamalat Indonesia telah sesuai dengan apa yang sudah ditetapkan oleh Ikatan Akuntansi Indonesia (IAI) dalam Pernyataan Standar Akuntansi Keuangan (PSAK) NO. 106 tentang ketentuan akuntansi musyarakah. Karena jika suatu bank laporan keuangannya tidak sesuai dengan Pernyataan Standar Akuntansi Keuangan (PSAK) maka semua yang dilakukan dalam laporan keuangan bank tersebut tidak akan diakui, maka tidak akan diterima oleh komisioner, maka laporan keuangan bank tersebut dianggap menjadi rancu. Karena Pernyataan Standar Akuntansi Keuangan (PSAK) sebagai standar, disusun berdasarkan praktisi, oleh karena itu akad muncul dari praktisi.

Dilihat dari proses analisis di atas ada bagian yang dijalankan oleh Bank Muamalat Kantor Cabang Pembantu Curup bahwa kesimpulan yang dapat peneliti simpulkan dari paparan di atas bahwa ada bagian yang kurang sesuai dengan Pernyataan Standar Akuntansi Keuangan (PSAK) NO. 106 tentang ketentuan musyarakah. Pada bagian penyajian yang seharusnya pembiayaan musyarakah yang diberikan dicatat dalam jurnal sebagai investasi musyarakah bukan seperti yang dilakukan oleh Bank Muamalat Kantor Cabang Pembantu Curup. Untuk lebih mudah memahami tersebut, dapat dilihat pada tabel di bawah ini: 
Soleha | Implementasi PSAK NO. 106 Akuntansi Musyarakah Pada Produk Pembiayaan Kepemilikan Rumah

\begin{tabular}{|c|c|}
\hline $\begin{array}{l}\text { Pernyataan Standar } \\
\text { Akuntansi Keuangan } \\
\text { (PSAK) N0. } 106 \text { tentang } \\
\text { ketentuan musyarakah }\end{array}$ & $\begin{array}{l}\text { Praktek Yang Dilakukan di } \\
\text { Bank Muamalat Kantor } \\
\text { Cabang Pembantu Curup }\end{array}$ \\
\hline $\begin{array}{l}\text { Pengakuan } \\
\text { a. Pada saat akad. } \\
\text { Investasi musyarakah } \\
\text { diakui pada saat } \\
\text { pembayaran kas atau } \\
\text { penyerahan aset } \\
\text { nonkas kepada mitra } \\
\text { aktif musyarakah. }\end{array}$ & $\begin{array}{l}\text { Pengakuan } \\
\text { a. Investasi musyarakah } \\
\text { yang disepakai oleh } \\
\text { bank (M) dan nasabah } \\
\text { (S) diakui pihak bank } \\
\text { pada saat pembayaran } \\
\text { kas kepada nasabah } \\
\text { yaitu sebesar Rp } \\
21.000 .000 \text { dengan } \\
\text { demikian dinyatakah } \\
\text { sesuai } \quad \text { dengan } \\
\text { Pernyataan Standar } \\
\text { Akuntansi Keuangan } \\
\text { (PSAK) No. 106 } \\
\text { tentang akuntansi } \\
\text { musyarakah. }\end{array}$ \\
\hline $\begin{array}{lr}\text { b. Pada saat akad. Biaya } \\
\text { yang terjadi akibat } \\
\text { akad musyarakah } \\
\text { (misalnya, biaya studi } \\
\text { kelayakan) tidak dapat } \\
\text { diakui sebagai bagian } \\
\text { investasi musyarakah } \\
\text { kecuali rada } \\
\text { persetujuan dari } \\
\text { seluruh r mitra } \\
\text { musyarakah. }\end{array}$ & $\begin{array}{lr}\text { b. Dalam } & \text { realisasi } \\
\text { pembiayaan } & \text { terdapat } \\
\text { biaya-biaya } & \text { yang } \\
\text { harus dikeluarkan } \\
\text { oleh pihak nasabah } \\
\text { untuk menentukan } \\
\text { kelayakan } & \text { akad } \\
\text { tersebut dan } & \text { tidak } \\
\text { dapat diakui } & \text { sebagai } \\
\text { bagian } & \text { dari } \\
\text { pembiayaan } & \text { ini } \\
\text { kecuali } & \text { ada } \\
\text { persetujuan } & \text { dari } \\
\text { seluruh mitra, sebesar } \\
\text { Rp 7.000.000 } & \text { (biaya } \\
\text { administrasi rran } & \text { dan } \\
\text { notaris). } & \text { sesuai } \\
\text { dengan Pernyataan } & \text { Ptandar Akuntansi } \\
\text { Keuangan (PSAK). }\end{array}$ \\
\hline
\end{tabular}




\begin{tabular}{|c|c|}
\hline $\begin{array}{lrr}\text { c. Pengakuan hasil usaha. } \\
\text { Pendapatan usaha } \\
\text { investasi musyarakah } \\
\text { diakui r sebagai } \\
\text { pendapatan sebesar } \\
\text { bagian mitra pasif } \\
\text { sesuai } & \text { kesepakatan. } \\
\text { Adapun rran } & \text { kerugian } \\
\text { investasi } & \text { musyarakah } \\
\text { diakui sesuai dengan } & \text { dengi dana }\end{array}$ & $\begin{array}{lr}\text { c. Laba masing-masing } \\
\text { pihak ditentukan } \\
\text { sesuai kesepakatan } \\
\text { bersama dari kedua } \\
\text { belah pihak yang } \\
\text { disetujui diawal akad. } \\
\text { Pada bulan juni 2000 } \\
\text { bank menerima } \\
\text { pendapatan r dari } \\
\text { nasabah sebesar Rp } \\
\text { 900.000 maka bank } \\
\text { langsung melalui laba } \\
\text { periode tersebut. } \\
\text { Dengan demikian } \\
\text { sesuai ryan } \\
\text { Pernyataan Standar } \\
\text { Akuntansi Keuangan } \\
\text { (PSAK). }\end{array}$ \\
\hline $\begin{array}{l}\text { d. Akhir akad. Pada saat } \\
\text { akad diakhiri investasi } \\
\text { musyarakah yang } \\
\text { belum dikembalikan } \\
\text { oleh mitra aktif diakui } \\
\text { sebagai piutang }\end{array}$ & 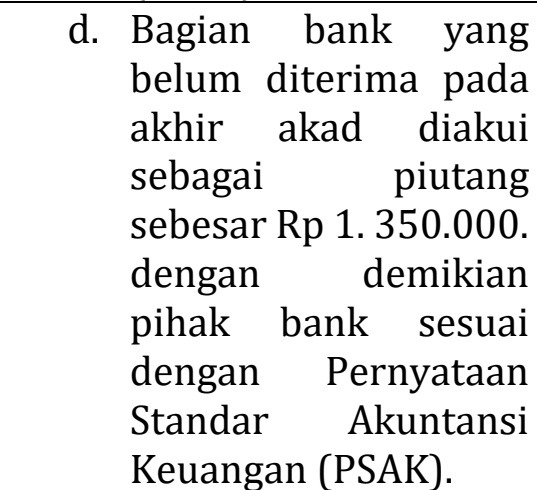 \\
\hline $\begin{array}{l}\text { Pengukuran } \\
\text { a. Pengukuran untuk } \\
\text { investasi musyarakah } \\
\text { dalam bentuk kas } \\
\text { dinilai sebesar jumlah } \\
\text { yang dibayarakan dan } \\
\text { dalam bentuk aset } \\
\text { nonkas dinilai sebesar } \\
\text { nilai wajar dan jika } \\
\text { terdapat selisih antara } \\
\text { nilai wajar dan nilai } \\
\text { tercatat aset nonkas, } \\
\text { selisih tersebut diakui }\end{array}$ & 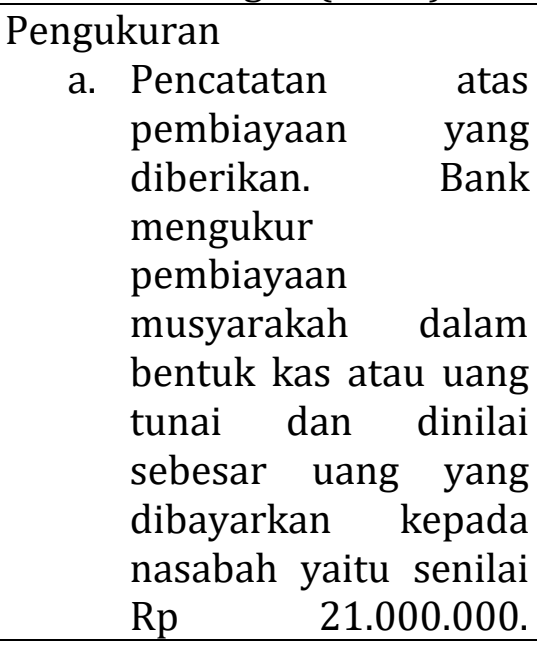 \\
\hline
\end{tabular}


Soleha | Implementasi PSAK NO. 106 Akuntansi Musyarakah Pada Produk Pembiayaan Kepemilikan Rumah

\begin{tabular}{|c|c|c|}
\hline & $\begin{array}{lr}\text { sebagai } & \text { keuntungan } \\
\text { tangguhan } & \text { dan } \\
\text { amortisasi } & \text { selama } \\
\text { masa akad atau } \\
\text { kerugian pada } & \text { saat } \\
\text { terjadinya. } & \\
\end{array}$ & $\begin{array}{l}\text { dengan } \\
\text { pihak bank sesuai } \\
\text { dengan Pernyataan } \\
\text { Standar Akuntansi } \\
\text { Keuangan (PSAK). }\end{array}$ \\
\hline b. & $\begin{array}{l}\text { Selama akad. Bagian } \\
\text { bank syariah atas } \\
\text { investasi musyarakah } \\
\text { dengan pengembalian } \\
\text { dana mitra akhir akad } \\
\text { dinilai sebesar jumlah } \\
\text { kas yang dibayarkan } \\
\text { untuk usaha } \\
\text { musyarakah pada awal } \\
\text { akad dikurangi dengan } \\
\text { kerugian apabila ada } \\
\text { atau nilai tercatat aset } \\
\text { musyarakah nonkas } \\
\text { pada saat penyerahan } \\
\text { untuk usaha } \\
\text { musyarakah setelah } \\
\text { dikurangi penyusutan } \\
\text { dan kerugian apabila } \\
\text { ada. }\end{array}$ & $\begin{array}{l}\text { b. Pencatatan atas } \\
\text { pelunasan } \\
\text { pembiayaan. } \\
\text { Pengembalian dana } \\
\text { bank atas investasi } \\
\text { musyarakah pada } \\
\text { akhir akad diukur } \\
\text { sebesar jumlah kas } \\
\text { atau uang tunai yang } \\
\text { dibayarkan pada awal } \\
\text { akad yaitu sebesar Rp } \\
\text { 21.000.000. dengan } \\
\text { demikian pihak bank } \\
\text { sesuair dengan } \\
\text { Pernyataan Standar } \\
\text { Akuntansi Keuangan } \\
\text { (PSAK). }\end{array}$ \\
\hline c. & $\begin{array}{lr}\text { Bagian bank } & \text { syariah } \\
\text { atas } & \text { investasi } \\
\text { musyarakah menurun } & \text { menuan } \\
\text { dengan pengembalian } \\
\text { dana mitra } r \text { secara } \\
\text { bertahap } & \text { dinilai } \\
\text { sebesar jumlah kas } \\
\text { yang dibayarkan untuk } \\
\text { usaha musyarakah } \\
\text { pada awal akad } \\
\text { dikurangi } & \text { jumlah } \\
\text { pengembalian } & \text { dari } \\
\text { mitra aktif } & \text { dan } \\
\text { kerugian jika ada. }\end{array}$ & $\begin{array}{lr}\text { Pencatatan } & \text { atas } \\
\text { penerimaan } & \\
\text { pendapatan bagi hasil } & \text { modal } \\
\text { beserta } & \text { pembiayaan } \\
\text { musyarakah yang } & \\
\text { dikembalikan pada } & \text { pertama. } \\
\text { tahun } & \text { Pengembalian dana } \\
\text { bank atas investasi } \\
\text { musyarakah menurun } \\
\text { diukur sebesar jumlah } \\
\text { kas yang disetorkan } \\
\text { pada awal akad } \\
\text { dikurangi jumlah } \\
\text { pengembalian dari }\end{array}$ \\
\hline
\end{tabular}




\begin{tabular}{|c|c|}
\hline & $\begin{array}{lr}\text { mitra aktif } & \text { dan } \\
\text { kerugian sebesar Rp } & \text { yang } \\
21.000 .000 & \text { yecara } \\
\text { dikembalikan } & \text { selama } \\
\text { bertahap } & \text { dimana } \\
\text { 8tahun, } & \text { modal } \\
\text { pertahunnya } & \text { dikembalikan } \\
\text { bank } & \text { sebesar Rp } 3.000 .000 \\
\text { dan ditambah dengan } & \text { pendapatan bagi hasil } \\
\text { pada tahun tersebut. } & \text { Dengan demikian } \\
\text { pihak bank sesuai } \\
\text { dengan Pernyataan } \\
\text { Standar Akuntansi } \\
\text { Keuangan (PSAK). }\end{array}$ \\
\hline $\begin{array}{l}\text { Penyajian } \\
\text { Mitra aktif menyajikan hal-hal } \\
\text { yang terkait dengan usaha } \\
\text { musyarakah dalam laporan } \\
\text { keuangan sebagai berikut: } \\
\text { a. Aset musyarakah } \\
\text { untuk kas atau aset } \\
\text { nonkas yang disisihkan } \\
\text { dan yang diterima dari } \\
\text { mitra pasif. }\end{array}$ & $\begin{array}{l}\text { Penyajian } \\
\text { Mitra aktif menyajikan hal- } \\
\text { hal yang terkait dengan usaha } \\
\text { musyarakah dalam laporan } \\
\text { keuangan sebagai berikut: } \\
\text { a. Pada saat realisasi } \\
\text { pembiayaan } \\
\text { musyarakah pihak } \\
\text { bank menyajikan } \\
\text { pencatatan dengan } \\
\text { mendebet } \\
\text { pembiayaan } \\
\text { musyarakah yang } \\
\text { diberikan sebesar Rp } \\
21.000 .000 \\
\text { mengkredit kas atau } \\
\text { rekening giro sebesar } \\
\text { Rp 21.000.000. } \\
\text { dengan demikian ini } \\
\text { tidak sesuai dengan } \\
\text { Pernyataan Standar } \\
\text { Akuntansi Keuangan } \\
\text { (PSAK). }\end{array}$ \\
\hline
\end{tabular}


Soleha | Implementasi PSAK NO. 106 Akuntansi Musyarakah Pada Produk Pembiayaan Kepemilikan Rumah

\begin{tabular}{|c|c|}
\hline $\begin{array}{l}\text { Mitra mengungkapkan dalam } \\
\text { lal-hal yang terkait transaksi } \\
\text { nusyarakah tetapi tidak } \\
\text { erbatas pada Isi kesepakatan } \\
\text { tama usaha musyarakah } \\
\text { eperti porsi penyertaan, } \\
\text { embagian hasil usaha, } \\
\text { ktivitas usaha musyarakah } \\
\text { lan lain-lain. Pengelola usaha } \\
\text { ika tidak ada mitra aktif. } \\
\text { engungkaan yang diperlukan } \\
\text { esuai pernyataan standar } \\
\text { lkuntansi keuangan No. } 101 \\
\text { entang Penyajian Laporan } \\
\text { Keuangan Syariah. }\end{array}$ & $\begin{array}{l}\text { Mitra mengungkapkan dalam } \\
\text { hal-hal yang terkait transaksi } \\
\text { musyarakah tetapi tidak } \\
\text { terbatas pada Isi kesepakatan } \\
\text { utama usaha musyarakah } \\
\text { seperti porsi penyertaan, } \\
\text { pembagian hasil usaha, } \\
\text { aktivitas usaha musyarakah } \\
\text { dan lain-lain. Pengelola usaha } \\
\text { jika tidak ada mitra aktif. } \\
\text { Pengungkaan yang } \\
\text { diperlukan sesuai pernyataan } \\
\text { standar akuntansi keuangan } \\
\text { No. 101 tentang Penyajian } \\
\text { Laporan Keuangan Syariah. }\end{array}$ \\
\hline
\end{tabular}

Untuk promosi sendiri berupa selebaran-selebaran yang dibagikan ke masyarakat ketika ada acara-acara tertentu atau ketika ulang tahun bank. Untuk pelayanan sendiri masyarakat bisa langsung datang ke bank yang nantinya akan dijelaskan oleh pihak yang bersangkutan. Produk yang paling diminati nasabah yaitu musyarakah mutanaqisah karena pembiayaan mempunyai jangka waktu yang sangat lama. Tidak ada hambatan dalam memasarkan pembiayaan, yang ada pihak bank kesulitan memilah banyaknya formulir masyarakat yang mengajukan pembiayaan. Kebanyakan dari nasabah mengetahui adanya bank ini dari televisi dan sebagian lainnya mengetahui dari mulut ke mulut.

Hanya ada satu kantor cabang di Curup yaitu di Jalan merdeka Curup. Kebanyakan dari mereka nasabah baru, semenjak gencarnya lembaga keuangan menerapkan sesuai dengan prinsip Islam. Tentu saja mempersulitkan nasabah, namun mereka semangat mendengarkan istilah-istilah baru. Karena mereka nasabah pembiayaan kepemilikan rumah tentu saja yang paling diminati adalah pembiayaan kepemilikan rumah. Selain itu ada juga produk dana pensiun, yang dapat membantu masyarakat untuk merencanakan impiannnya ke depan atau masa tuanya nanti. Pelayanan yang diberikan oleh Bank Muamalat Kantor Cabang Pembantu Curup sangat baik, ramah, jelas. 


\section{Kesimpulan}

Dari penelitian yang dilakukan dapat disimpulkan bahwa pembiayaan kepemilikan rumah pada bank Muamalat memiliki 2 pilihan akad yaitu murabahah dan muasyaraah mutanaqisah yang nantinya akan disesuaikan dengan kebutuhan nasabah. Kedua akad yang dipergunakan memiliki fungsi dan perbedaan tertentu. Dari penelitian yang dilakukan didapat hasil bahwa bank muamalat kantor cabang pembantu cutup sudah menerapkan pernyataan standar akuntansi keuangan (PSAK) yang dikeluarkan oleh Ikatan Akuntansi Indoneasia (IAI) telah diterapkan oleh bank muamalat. Penerapan pernyataan standar akuntansi keuangan meliputi pengakuan, pengukuran, penyajian dan pengungkapan.

Dari hasil pengamatan didapat beberapa hal yang dapat dan perlu disarankan oleh peneliti yaitu dimana bank muamalat seharusnya lebih banyak mengadakan sosialisai kepada masyarakat khsuusnya masyarakat kota curup. Memberikan pemahaman yang nantinya akan tergerak kesadaran dalam diri dari masyarakat akan kehadiran bank syariah. Bank sebagai lembaga keuangan yang kita ketahui hendaknya ikut serta dalam sisi sosial seperti pembangunan ekonomi bangsa, menjaga kesyariahannya terhadap produk-produk yang ditawarkan ke masyarakat serta memperhatikan apa yang diimplemntasikan haruslah sesuai dengan syariah.

\section{Bibliografi}

Ashsiddiqqy, M. R., Monoarfa, H., \& Cakhyaneu, A. (2020). Implementation of Aqad Musyarakah Mutanaqisah (MMQ) Take Over Financing on KPR Products in Sharia Banks. Review of Islamic Economics and Finance. https://doi.org/10.17509/rief.v1i1.23745

Hajaru, F., \& Hardivizon, H. (2016). Individual Experience dan Persepsi Pedagang: Relasi Pengalaman Individual Dan Persepsi Pedagang Terhadap Bank Syariah. AL-FALAH : Journal of Islamic Economics, 1(1), 89-104. https://doi.org/10.29240/jie.v1i1.63

Hardivizon, \& Sholihin, M. (2021). Hybrid Rationality behind Customers' Choices of the Islamic Banks: An Experience of Bengkulu, Indonesia. Journal of Islamic Thought and Civilization, 11(1), 175200. https://doi.org/10.32350/jitc.111.10

Pribadi, R. W. (2019). PEMBIAYAAN HUNIAN SYARIAH KONGSI AKAD 
Soleha | Implementasi PSAK NO. 106 Akuntansi Musyarakah Pada Produk Pembiayaan

Kepemilikan Rumah

MUSYARAKAH MUTANAQISAH PERSPEKTIF UNDANG-UNDANG NO. 21 TAHUN 2008 TENTANG PERBANKAN SYARIAH. Mutawasith: Jurnal Hukum Islam, 2(1), 65-90. https://doi.org/10.47971/mjhi.v2i1.146

Rahmat, E. (2019). ANALISA PEMBIAYAAN PROPERTI MENGGUNAKAN AKAD MMQ (MUSYARAKAH MUTANAQISAH). El-Arbah: Jurnal Ekonomi, Bisnis Dan Perbankan Syariah, 2(02), 1-26. https://doi.org/10.34005/elarbah.v2i02.540

Rohmi, P. K. (2020). Implementasi Akad Musyarakah Mutanaqishah Pada Pembiayaan Kepemilikan Rumah Di Bank Muamalat Lumajang. Iqtishoduna.

Zainuddin, M. A. (2018). AKAD MUSYARAKAH MUTANAQISAH DALAM SISTEM PERBANKAN SYARIAH. Bilancia: Jurnal Studi Ilmu Syariah Dan Hukum, 12(2), 321-338. https://doi.org/10.24239/blc.v12i2.373 